\begin{tabular}{|c|c|c|}
\hline BIODIK & $\begin{array}{c}\text { BIODIK: Jurnal IImiah Pendidikan Biologi } \\
\text { ISSN 2580-0922 (online), ISSN 2460-2612 (print) } \\
\text { Volume 6, Nomor 04, Tahun 2020, Hal. 550-561 } \\
\text { Available online at: } \\
\text { https://online-journal.unja.ac.id/biodik }\end{array}$ & BIODIK \\
\hline
\end{tabular}

Research Article

open ACCESS

\title{
Analisis Kesesuaian Lembar Kerja Menggunakan Metode Ancor pada Praktikum Plasmolisis pada Sel Tumbuhan
}

\section{(The Comformity Analysis of Worksheets using an Ancor Method in The Practical Work of Plasmolysis Observation in Plant Cells)}

\author{
Intania Zainal Nurul Huda*, Sri Anggraeni, Bambang Supriatno \\ Universitas Pendidikan Indonesia \\ JI. Dr. Setiabudi No. 229 Kota Bandung, Jawa Barat - Indonesia \\ *Corresponding Author: intania.zainal@upi.edu
}

\begin{tabular}{|c|c|}
\hline Informasi Artikel & ABSTRACT \\
\hline $\begin{array}{l}\text { Submit: } 31-05-2020 \\
\text { Diterima: } 12-08-2020 \\
\text { Dipublikasikan: } 19-12-2020\end{array}$ & $\begin{array}{l}\text { Biology as science is not detached from the demands to help students gain an } \\
\text { understanding as much as possible of scientific knowledge in accordance with their } \\
\text { needs and also able to develop students ' understanding of the methods that } \\
\text { knowledge is acquired. One of the many methods used in biological learning is the } \\
\text { practical work. To learn using the practical work is not separated from the needs of } \\
\text { worksheets, yet some worksheets that teachers use sometimes do not comply with } \\
\text { what should be, according to the prevailing curriculum demands. Therefore, this } \\
\text { research aims to analyse the conformity of worksheets by using Analysis, Trial and } \\
\text { Reconstruction (ANCOR) methods. The study was conducted by taking six } \\
\text { worksheets that selected according to the worksheet which is commonly used in } \\
\text { practical activity of plasmolysis observation in plant cells. This research is included in } \\
\text { qualitative descriptive. The instrument used is an analysis of the conformity of } \\
\text { worksheets that was conducted from the research carried out by Wahidah, et.al. } \\
\text { (2018) and also analyses using a Vee diagram rubric adapted from research } \\
\text { conducted by Supriatno (2013). The results of the study found that the worksheets } \\
\text { used in the practice of Plasmolysis observation is still less appropriate to be used as } \\
\text { a good for practical activities and still in low conformity based on the analysis of the } \\
\text { Vee diagram. } \\
\text { Keywords: Worksheet, Practical Work, Plasmolysis }\end{array}$ \\
\hline Penerbit & ABSTRAK \\
\hline $\begin{array}{l}\text { Program Studi Pendidikan } \\
\text { Biologi, Fakultas Keguruan dan } \\
\text { IImu Pendidikan, Universitas } \\
\text { Jambi-Indonesia }\end{array}$ & $\begin{array}{l}\text { Biologi sebagai ilmu sains menuntut pemahaman tentang pengetahuan ilmiah yang } \\
\text { sesuai dengan kebutuhan dan mampu mengembangkan pemahaman metode atau } \\
\text { cara pengetahuan itu diperoleh. Salah satu metode yang digunakan pada } \\
\text { pembelajaran biologi adalah metode praktikum. Pembelajaran menggunakan metode } \\
\text { praktikum tidak terlepas dari adanya kebutuhan Lembar Kerja Peserta Didik (LKPD) } \\
\text { yang sesuai, namun LKPD yang digunakan guru terkadang tidak sesuai dengan } \\
\text { tuntutan kurikulum yang berlaku. Untuk itu, penelitian ini bertujuan untuk } \\
\text { menganalisis kesesuaian pada LKPD yang digunakan dengan menggunakan metode } \\
\text { Analisis, uji Coba dan Rekontruksi (ANCOR). Penelitian dilakukan dengan } \\
\text { mengambil enam LKPD yang dipilih berdasarkan LKPD yang biasa digunakan dalam } \\
\text { kegiatan praktikum pengamatan plasmolisis pada sel tumbuhan. Penelitian ini } \\
\text { termasuk ke dalam penelitian deskriptif kualitatif karena besifat menggambarkan } \\
\text { hasil dari penelitian. Instrumen yang digunakan berupa analisis kesesuaian LKPD } \\
\text { yang diadptasi dari penelitian yang dilakukan oleh Wahidah, et.al. (2018) dan juga } \\
\text { analisis menggunakan rubrik diagram vee yang diadaptasi dari penelitian yang } \\
\text { dilakukan oleh Supriatno (2013). Hasil penelitian ditemukan bahwa LKPD yang } \\
\text { digunakan pada praktikum pengamatan plasmolisis masih kurang sesuai untuk } \\
\text { dijadikan LKPD yang baik dan masih berada pada kualitas yang rendah berdasarkan } \\
\text { analisis dari diagram vee. } \\
\text { Katakunci: Lembar Kerja, Kegiatan praktikum, Plasmolisis }\end{array}$ \\
\hline
\end{tabular}


Attribution-ShareAlike 4.0 International License)
Pis B

\section{PENDAHULUAN}

Biologi merupakan salah satu bidang ilmu sains yang pembelajarannya mencakup segala tentang mahluk hidup dan aspek yang mendukung kehidupannya (Sudarsiman, 2015). Biologi sebagai ilmu praktis, yang memiliki eksperimen dan kegiatan investigasi yang berkualitas tinggi dan tepat sebagai kunci untuk meningkatkan pembelajaran, konsolidasi teori dan klarifikasi. Pendidikan sains sendiri memiliki tujuan untuk membantu peserta didik memperoleh pemahaman tentang sebanyak mungkin pengetahuan ilmiah yang sesuai dengan kebutuhan, minat dan kapasitas mereka, selain itu pendidikan sains juga mampu mengembangkan pemahaman peserta didik tentang metode-metode atau cara pengetahuan itu diperoleh dan alasan peserta didik mempercayai hasil dari pengetahuannya (millar, 2004).

Kurikulum dalam pembelajaran sains di sekolah menuntut peserta didik untuk memiliki pengetahuan dan keahlian ilmiah dan menekankan salah satunya, yaitu keterampilan melaksanakan metode ilmiah dalam hal ini kerja praktek. Permasalahan di lapangan secara nyata memperlihatkan bahwa desain kegiatan praktikum di sekolah yang disajikan pada sebuah Lembar Kerja Peserta Didik (LKPD) tidak memiliki kualitas sebagaimana mestinya (Supriatno, 2013). Selain daripada itu, permasalahan yang sama ditemukan pula pada penelitian yang dilakukan oleh Wahidah (2018) bahwa kegiatan praktikum yang dilaksanakan oleh siswa memiliki tujuan praktikum yang tidak jelas, dan memperlihatkan ketidak sesuaian fakta/peristiwa yang muncul seperti yang diinginkan. Hal tersebut akan berpengaruh terhadap proses rekontruksi pengetahuan yang seharusnya didapatkan oleh siswa sebagai hasil yang diinginkan dari sebuah kegiatan praktikum. Sebuah kegiatan praktikum, tidak hanya dapat memotivasi peserta didik dan bersifat menyenangkan, tetapi kegiatan praktikum memungkinkan peserta didik untuk dapat menerapkan dan memperluas pengetahuan dan pemahaman mereka tentang biologi, dapat merangsang minat, dan membantu dalam pembelajaran (Emda, 2014). Kegiatan praktikum juga sangat diperlukan untuk menunjang materi ajar sehingga mampu membantu peserta didik memahami konsep-konsep yang sulit dan abstrak (Umbayarti, 2016). Pembelajaran menggunakan metode praktikum tidak terlepas dari adanya kebutuhan Lembar Kerja Peserta Didik (LKPD) yang sesuai dengan tujuan dari pembelajaran. Lembar Kerja Peserta Didik (LKPD) merupakan sarana untuk membantu dan mempermudah dalam kegiatan belajar mengajar sehingga terbentuk interaksi efektif anatara peserta didik dengan pendidik dan mampu meningkatkan aktivitas dan prestasi belajar dari peserta didik (Umbayarti, 2016). Penggunaan LKPD dianggap dapat memberikan kemudahan untuk peserta dalam menunjukan 
kemampuan pengetahuan, pemahaman dan keterampilan terhadap suatu materi (Mentari, 2017). Tujuan dari penyusunan LKPD adalah untuk memperkuat, menunjang tujuan pembelajaran, ketercapaian indikator serta kompetensi dasar dan kompetensi inti; serta membantu peserta didik untuk mencapai tujuan pembelajaran.

Lembar Kerja Peserta Didik (LKPD) di definisikan sebagai bahan ajar cetak berupa lembar-lembar kertas yang berisi materi, ringkasan dan petunjuk-petunjuk pelaksanaan tugas yang harus dikerjakan oleh peserta didik, yang mengacu pada kompetensi dasar yang dicapai (Andi prastowo, 2011:204). Penelitian sebelumnya yang dilakukan oleh Afsari (2017) setelah melakukan survey pada guru bidang studi Biologi SMA di Makassar menunjukan bahwa LKPD mengenai materi sel yang digunakan dalam pembelajaran belum menuntut peserta didik untuk berpikir tingkat tinggi. Selain daripada itu, LKPD biologi yang digunakan merupakan LKPD yang di ambil dari internet dan buku teks pelajaran belum sepenuhnya sesuai dengan tujuan pembelajaran yang dituntut oleh kurikulum. Hal ini sesuai dengan hasil dari studi lapangan yang dilakukan oleh Supriatno (2009) menemukan bahwa hanya $24 \%$ desain kegiatan praktikum laboratorium yang dapat dikerjakan desuai dengan prosedur dan tuntas dari segi analisis data dan penarikan kesimpulan. Supriato (2013) menemukan bahwa desain kegiatan laboratorium yang beredar di lapangan memiliki permasalahan dari segi tujuan praktikum, penggunaan pendekatan deduktif dengan modal eksposition, prosedur praktikum tidak terstruktur dan membingungkan, serta pemilihan materi yang tidak mempertimbangkan esensi, kesesuaian, kedalaman dan kompleksitas materinya.

Pada penelitian ini peneliti memilih untuk menganalisis dan menguji coba Lembar Kerja Peserta Didik (LKPD) mengenai materi transport membran yang berhubungan dengan proses osmosis. Hal ini dikarenakan pemahaman peserta didik tentang fenomena difusi maupun osmosis sebagai proses yang terjadi pada transport membran merupakan prasyarat dasar pemahaman mereka tentang fungsi biologis tertentu, khususnya mengenai sel. Beberapa penelitian memperlihatkan ketertarikan pada pengajaran dan pembelajaran konsep difusi dan osmosis, beberapa menggambarkan konsepsi peserta didik mengenai fenomena biologis ini, sementara yang lain berfokus pada strategi pengajaran yang cenderung mendorong penguasaan konsep peserta didik (Hasni, 2016). Penelitian yang dilakukan Hasni (2016) mengungkapkan bahwa selama 20 tahun terakhir, beberapa penelitian telah menunjukkan bahwa peserta didik memiliki konsepsi yang tidak memadai mengenai transport membran dan pemahaman tentang kedua fenomena ini tidak lengkap. Namun daripada itu, beberapa studi telah memberikan hasil yang baik dalam pengajaran mengenai osmosis menggunakan pendekatan laboratorium daripada pembelajaran secara konvensional. Penelitian sebelumnya yang dilakukan oleh Oztas (2013) menggambarkan bahwa praktik kelas otentik menfasilitasi pemahaman konsep difusi dan osmosis oleh peserta didik atau praktik yang merupakan sumber kesulitan yang dijadikan salah satu literatur oleh penelitian ini.

Plasmolisis merupakan perisiwa atau respon yang dapat terjadi akibat adanya proses osmosis yang terjadi. Plasmolisis merukan respon dari sel-sel tumbuhan yang

\section{Hudah, dkk}


terpapar oleh adanya larutan hypertonis (Lang, et. al., 2014). Hilangnya turgor menyebabkan lepasnya protoplasma yang melekat di dinding sel. Proses plasmolitik didorong oleh adanya vakuola dan peritiwa ini bersifat reversible (dapat kembali ke keadaan normal/deplasmolisis) dan bersifat khas bagi sel tanaman hidup (Lang, et.al., 2014). Penelitian ini memiliki tujuan untuk menganalisis kesesuaian Lembar Kerja Peserta Didik (LKPD) pada kegiatan praktikum pengamatan palsmolisis pada sel tumbuhan Rheo discolour yang biasa di gunakan oleh guru sebagai bahan ajar dan diberikan pada peserta didik Selain itu, hasil analisis lembar kerja peserta didik ini di uji coba dan di rekontruksi oleh peneliti dengan tujuan menghasilkan lembar kerja yang lebih baik.

\section{METODE PENELITIAN}

Penelitian ini merupakan penelitian deskriptif kualitatif. Penelitian kualitatif adalah prosedur penelitian yang menghasilkan data deskriptif berupa kata-kata tertulis atau lisan dari perihal yang diamati (Sugiyono, 2016: 15). Metode penelitian yang dilaksanakan menggunakan metode ANCOR, dimana LKPD terlebih dahulu di analisis, kemudian di uji coba dan direkontruksi. LKPD yang dianalisis oleh peneliti terdiri atas enam LKPD yang berhubungan dengan pengamatan plasmolisis pada tumbuhan. Pengambilan sampel ialah dengan mengambil seluruh sampel yang ditemukan yang sekiranya merupakan LKPD praktikum pengamatan plasmolisis yang di dapat dari buku teks pelajaran dan LKPD buatan guru mata pelajarann biologi. Hal yang didahulukan oleh peneliti adalah menganalisis LKPD yang dijadikan sumber data, dan melihat bagaiman isi LKPD tersebut dan ketersesuaian LKPD dengan tujuan pembelajaran yang ingin dicapai yang merujuk pada kompetensi dasar pada kurikulum yang berlaku. Instrumen yang digunakan adalah analisis konseptual, praktikal dan rekontruksi pengetahuan yang diadaptasi dari penelitan Wahidah, et.al. (2018) dengan rincian jenis analisis dan indikatornya disajikan dalam tabel berikut.

Tabel 1. Indikator Analisis Kesesuaian LKPD yang diadopsi dari penelitian Wahidah, et.al. (2018) Jenis Analisis

\begin{tabular}{ll}
\hline Analisis Konseptual & Kesesuaian konten LKPD dengan kurikulum \\
& Kesesuaian kompetensi LKPD dengan kurikulum \\
& Kesesuaian Judul dan tujuan kegiatan \\
& Kesesuaian kegiatan dengan tingkat kognitif peserta didik \\
\hline Analisis praktikal & Ketersediaan alat dan bahan yang digunakan \\
& Prosedur kerja yang terstruktur dan dapat dieksekusi \\
& Kesesuaian object event \\
& Kesesuaian perekaman data \\
& Kesesuaian fenomena objek dengan tujuan kegiatan \\
& Kesesuaian waktu pengerjaan \\
& Kesesuaian prosedur kerja \\
\hline Analisis Kontruksi & Terdapat jawaban pertanyaan tanpa pelaksaan praktikum \\
pengetahuan & Terdapat fakta yang muncul \\
& Terdapat fakta untuk mengkontruksi prinsip \\
& Terdapat proses interpretasi data \\
& Terdapat pertanyaan terkait kemunculan prinsip \\
& Terdapat pertanyaan untuk melakukan analisis \\
& Terdapat penarikan kesimpulan yang menggambarkan tujuan \\
\hline
\end{tabular}


Selain dari penggunaan instrument di atas, kesesuaian LKPD mengenai pengamatan plasmolisis pada sel tumbuhan pun dianalisis menggunakan rubrik diagram vee yang diadopsi dari penelitian Supriatno (2013) yang disajikan dalam tabel berikut.

Tabel 2. Rubrik Penskoran Komponen Lembar Kerja Peserta Didik (LKPD) Berdasarkan Diagram Vee diadaptasi dari Supriatno (2013)

\section{Indikator}

\section{Focus question}

1. Tidak ada focus question yang dapat diidentifikasi.

2. Pertanyaan (question) dapat diidentifikasi, tetapi tidak memfokuskan kepada hal utama yang berkaitan dengan objek dan peristiwa (events) atau tidak mengandung bagian konseptual terutama prinsip.

3. Focus question dapat diidentifikasi serta mengandung bagian konseptual tetapi tidak mendukung kepada observasi objek atau peristiwa utama

4. Focus question dengan jelas dapat diidentifikasi, meliputi bagian konseptual yang dapat digunakan serta mendukung peristiwa utama dan memperkuat objek.

\section{Objects/ events}

1. Tidak ada objek atau peristiwa yang dapat diidentifikasi.

2. Peristiwa utama atau objek dapat diidentifikasi dan konsisten dengan focus question, atau peristiwa dan objek dapat diidentifikasi tetapi tidak konsisten dengan focus question.

3. Peristiwa utama disertai dengan objek dapat diidentifikasi dan konsisten dengan focus question.

4. Sama dengan yang di atas, tetapi juga mendukung dengan apa yang akan ditulis.

\section{Theory, principles, and concepts}

1. Tidak ada bagian konseptual yang dapat diidentifikasi.

2. Sedikit konsep yang dapat diidentifikasi, tetapi tanpa prinsip-prinsip serta teori, atau sebuah prinsip yang tertulis merupakan pengetahuan yang diperoleh dari kegiatan laboratorium.

3. Konsep-konsep dan kurang lebih satu prinsip (konseptual atau metodologi) atau konsep-konsep dan sebuah teori yang relevan dapat diidentifikasi.

4. Konsep-konsep dan dua jenis prinsip dapat diidentifikasi, atau konsep-konsep, satu prinsip, dan sebuah teori yang relevan dapat diidentifikasi.

5. Konsep-konsep, dua bentuk prinsip, dan teori yang relevan dapat diidentifikasi.

\section{Records/ transformations}

1. Tidak ada kegiatan pencatatan atau transformasi dapat diidentifikasi.

2. Kegiatan pencatatan dapat diidentifikasi, tetapi tidak konsisten dengan pertanyaan utama atau kegiatan utama.

3. Kegiatan pencatatan atau transformasi atau peristiwa dapat diidentifikasi.

4. Kegiatan pencatatan dapat diidentifikasi dan sesuai dengan peristiwa utama: transformasi tidak konsisten dengan focus question.

5. Kegiatan pencatatan dapat diidentifikasi pada kegiatan utama: transformasi konsisten dengan focus question dan tingkat kualitas serta kemampuan peserta didik.

\section{Knowledge claim}

1. Tidak ada knowledge claim yang dapat diidentifikasi.

2. Knowledge claim tidak sesuai dengan bagian kiri Diagram Vee.

3. Knowledge claim tidak konsisten dengan data dan atau peristiwa yang dicatat dan ditransformasikan atau knowledge claim sudah mengandung conceptual side.

4. Knowledge claim mengandung konsep-konsep yang sesuai dengan focus question dan sesuai dengan hasil pencatatan dan transformasi.

5. Knowledge claim mengandung konsep-konsep yang sesuai dengan focus question dan sesuai dengan hasil pencatatan dan transformasi, tetapi knowledge claim mengarah kepada pembentukan focus question yang baru. 
Setelah analisis dilakukan, kegiatan yang diberikan pada LKPD yang dipilih di uji coba untuk dilakukan oleh peneliti guna melihat efektifitas praktikum dan ketercapaian hasil kegiatan praktikum yang dilaksanakan. Setelah dianalisis dan diuji coba peneliti mencoba untuk merekontruksi Lembar Kerja Peserta Didik yang dianggap peneliti sesuai dengan tujuan pembelajaran yang dituntut oleh kurikulum.

\section{HASIL DAN PEMBAHASAN}

Hasil analisis yang dilakukan pada keenam Lembar Kerja Peserta Didik (LKPD) bedasarkan analisis konseptual, analisis praktikal dan analisis rekontruksi pengetahuan, memperlihatkan grafik jumlah LKPD di setiap indikator pada gambar 1.

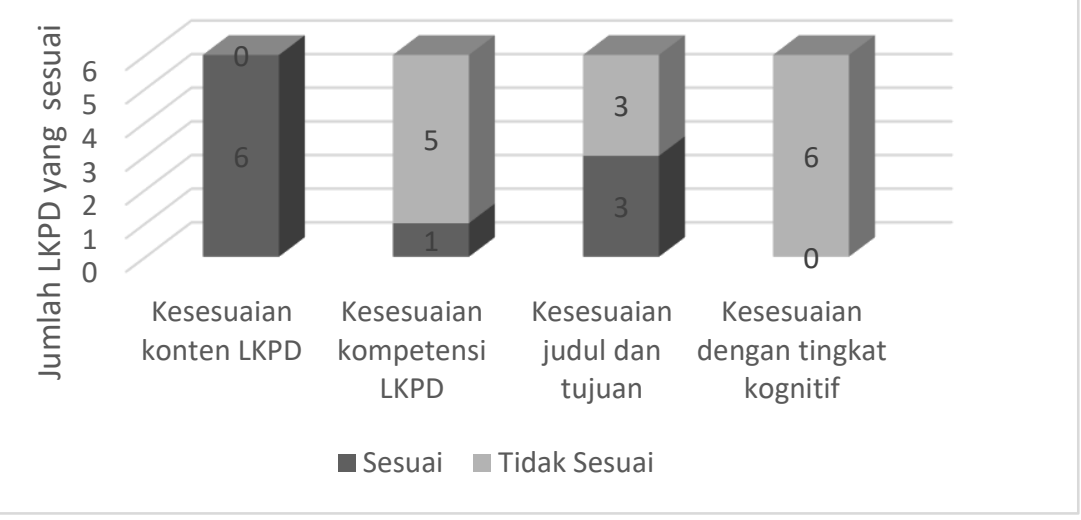

Gambar 1. Hasil Analisis Konseptual pada LKPD

Berdasarkan hasil analisis konseptual dari keenam LKPD (Gambar 1.) memperlihatkan bahwa hampir seluruh LKPD memiliki ketidaksesuaian antara kompetensi kegiatan praktikum dengan kompetensi yang diharapkan oleh kurikulum, selain itu tingkat kognitif peserta didik yang ingin dicapai oleh kegiatan praktikum pun tidak sesuai. Hal ini menunjukkan bahwa pada dasarnya kualitas LKPD dikategorikan kurang untuk digunakan. Menurut Rahmatilla, et.al. (2017) dalam penyusunan lembar kerja peserta didik untuk kegiatan praktikum hendaknya menjadikan kompetensi dasar sebagai rujukan dari tujuan dan capaian kognitif peserta didik. Dari hasil analisis konseptual juga masih ada LKPD yang belum sesuai anatra tujuan dan kegiatan dari praktikum. Widjajanti (2008) yang menyatakan bahwa LKPD merupakan sumber belajar yang perlu dikembangkan oleh guru dalam penyusunannya yang dapat mengajak peserta didik belajar secara mandiri dan akif mencari pemahaman dari hasil kegiatan pemebalajaran. 


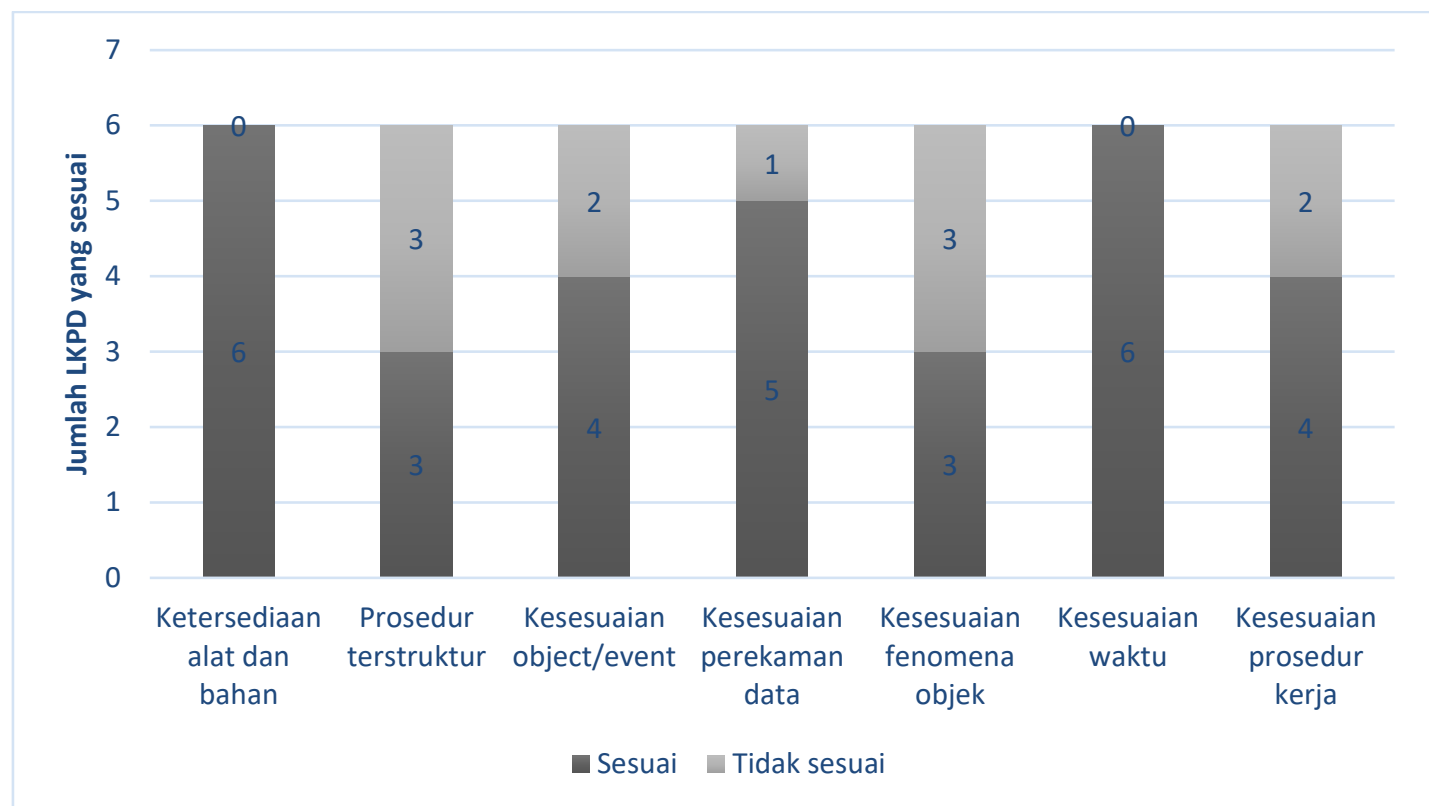

Gambar 2. Hasil Analisis Praktikal pada LKPD

Menurut Katriani (2014) penyusunan LKPD memerlukan tujuan kegiatan yang sesuai dengan tujuan pembelajaran dan ketercapaian indikator dari kopetensi dasar dan kompetensi inti yang sesuai dengan kurikulum yang berlaku. Dari indikator ini perlu adanya rekontruksi pada LKPD yang disesuaikan dengan capaian yang diinginkan oleh Kurikulum 2013 yang sedang berlaku di Indonesia yakni menganalisis berbagai proses yang terjadi di pada sel yang meliputi mekanisme transpor membran, reproduksi, dan sintesis protein, sehingga LKPD sebaiknya direkonstruksi sehingga tidak hanya melakukan kegiatan mengamati peristiwa plasmolisis, namun juga akan lebih baik terdapat proses menganalisis yang dapat dihubungkan pada sesuatu yang kontekstual yang dapat menimbulkan peristiwa plasmolisis pada mahluk hidup di lingkungan nyata. Hasil rekontruksi LKPD juga sebaiknya mencantumkan tuntutan kompetensi dasar pada bidang keterampilan, yakni peserta didik dituntut untuk dapat membuat model bioproses yang terjadi di dalam sel, ini dapat menjadi sesuatu yang baru dan dimasukkan sebagai produk setelah pelaksanaan praktikum dilakukan.

Pada analisis praktikal yang digambarkan pada grafik (Gambar 2.) memperlihatkan hasil bahwa tiga LKPD memperlihatkan ketidaksesuaian dari struktur prosedur dan juga terdapat pula tiga LKPD yang tidak sesuai antara tujuan dan fenomena objek. Hal ini selaras dengan hasil dari uji coba yang didapatkan peneliti, terdapat LKPD yang menggunakan berbagai macam larutan garam yang berbeda konsentrasi, namun tujuan kegiatan praktikum hanya menuntut siswa mengamati fakta gejala plasmolisis. Tentu saja, penggunaan bahan larutan garam yang begitu banyak tidak diperlukan apabila hanya untuk mengamati. Namun apabila kita rekontruksi, kita dapat menambahkan tujuan dari kegiatan praktikum untuk membandingkan pengaruh berbagai macam konsentrasi zat hipertonik terhadap keadaan sel tumbuhan.

\section{Hudah, dkk}




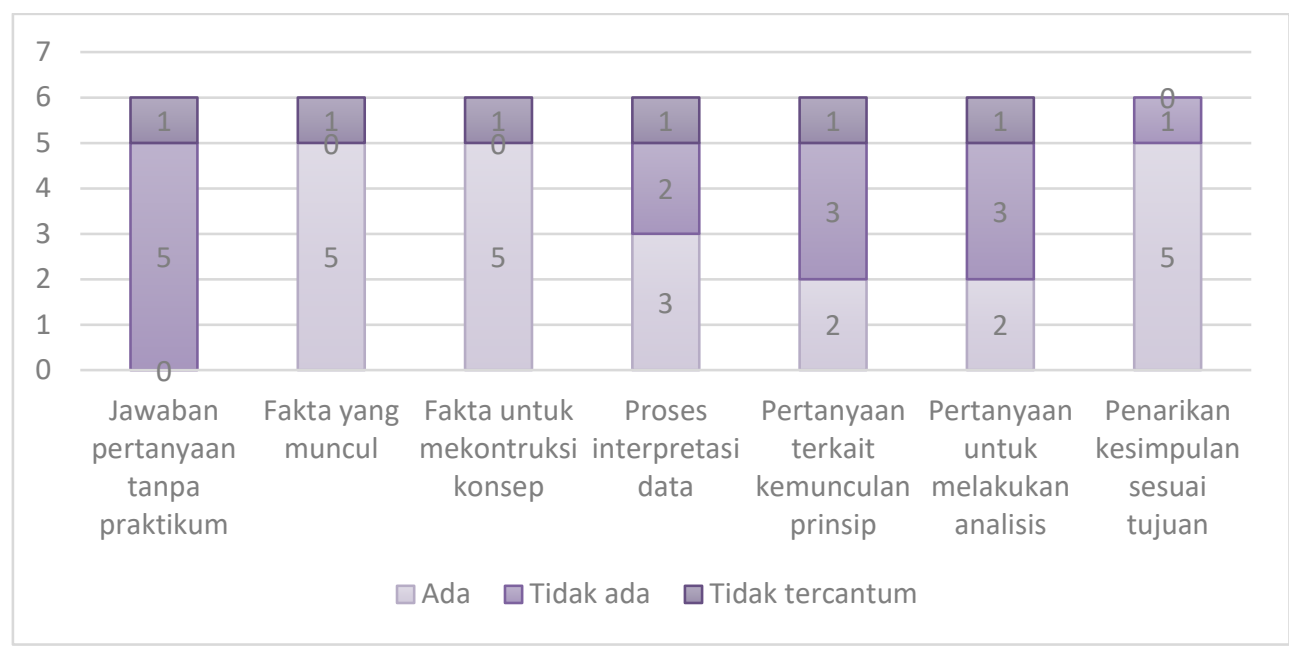

Gambar 3. Hasil Analisis Rekonstruksi Pengetahuan pada LKPD

Supriatno (2013) menyatakan bahwa prosedur praktikum yang meskipun terlihat rinci, beberapa diantaranya tidak tersetruktur dan perintahnya membingungkan sehingga menimbulkan penafsiran ganda. Bahkan akan lebih baik diberikan gambar sebagai ilusrasi. Jika terjadi kesalahan pada prosedur, maka kemungkinan tujuan yang diharapkan tidak tercapai. Hal ini juga didapatkan oleh penelitian yang dilakukan oleh Wahidah, et.al. (2018) yang menyatakan bahwa kebingungan akibat ketidakjelasan rangkaian pernyataan langkah kerja mampu memberikan kebingungan pada peserta didik dan dapat menyebabkan ketidaktercapaian tujuan dari kegiatan praktikum. Dari penyataan tersebut dapat dipastikan bahwa ketidakteraturan prosedur kerja pada kegiatan praktikum akan menghambat proses pembelajaran dan ketercapaian dari tujuan pembelajaran. Untuk itulah diperlukan prosedur kerja yang benar untuk memberikan pemahaman pada peserta didik terkait konsep plasmolisis.

Pada hasil analisis rekonstruksi pengetahuan yang disajikan pada grafik di atas (Gambar 3.), ditemukan bahwa seluruh LKPD yang dibuat mememberikan pertanyaan setelah pelaksanaan praktikum yang membutuhkan jawaban berdasarkan kegiatan praktikum. Hal ini baik, mengingat kegiatan praktikum pada pelajaran biologi merupakan proses pengamatan dan percobaan dalam rangka memahami permasalah objek biologi dan menerapkan hasil kegiatan tersebut untuk memecahkan masalah yang ada (Suryaningsih, Yeni. 2017). Namun tiga dari enam LKPD memperlihatkan bahwa pertanyaan untuk membangun pengetahuan tidak mengarahkan siswa untuk menemukan prinsip dari konsep-konsep yang ditemukan juga tidak menuntut siswa untuk dapat melakukan analisis. Sedangkan menurut Hartono, et.al. (2014) pengembangan LKPD hendaknya menjadikan peserta didik dapat menemukan fakta-fakta, membangun konsep, teori hingga prinsip yang dapat berpengaruh positif pada proses pendidikan. 
Analisis terhadap enam LKPD mengenai penagmatan plasmolisis pada sel tumbuhan pun dilanjutkan dengan analisis menggunakan rubrik diagram vee untuk melihat kualitas dari masing-masing LKPD. Hasil analisis disajikan pada grafik berikut.

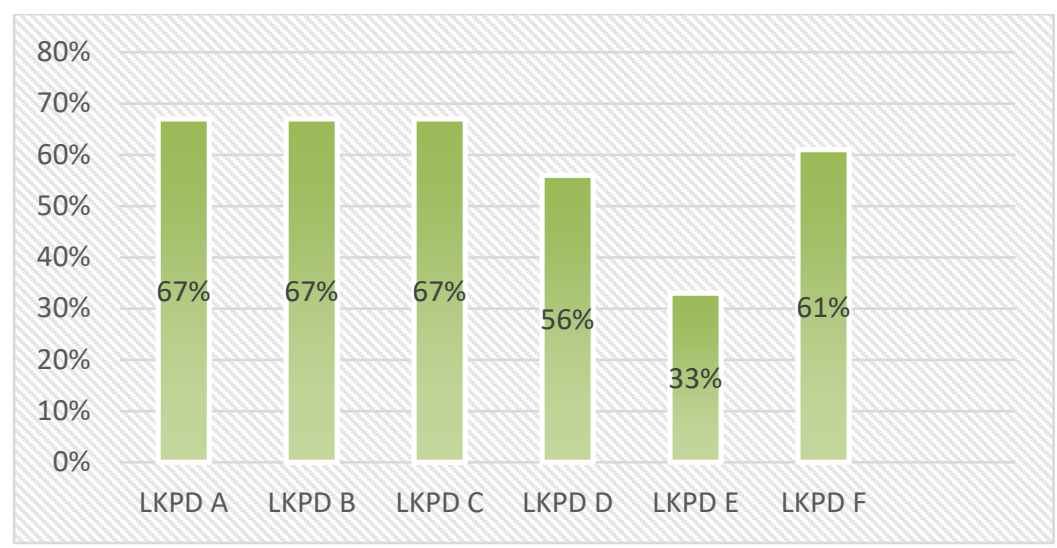

Gambar 4. Analisis Kesuaian LKPD berdasarkan Rubrik Diagram Vee

Diagram vee merupakan sebuah alat yang dapat digunakan untuk membantu memecahkan masalah atau memahami suatu prosedur (Novak \& Gowin, 1984). Diagram vee memiliki dua sisi yang saling mendukung yakni sisi konseptual (berfikir dan sisi metodologis (bekerja) (Huzaifah, etl.al., 2017). Kedua sisi ini saling berinteraksi untuk dapat merepresentasikan teori kontruktivisme dalam memperoleh pengetahuan, sehingga kesesuaian LKPD untuk dapat dikategorikan baik digunakan dalam pembelajaran dapat berpedoman pada diagram vee. Berdasarkan grafik yang disajikan di atas (Gambar 4.) memperlihatkan bahwa seluruh LKPD yang dianalisis hanya memiliki kesesuaian sebanyak $67 \%$ dengan indikator-indikator pada diagram vee. Hal ini termasuk kategori yang kurang baik, dikarenakan hanya mampu medapatkan skor 11 dari 18 skor sempurna. Bahkan, pada LKPD E memperlihatkan persentase kesesuaian yang sangat rendah yang hanya berada di angka 33\% dari seluruh indikator berdasarkan diagram vee.

Hasil tersebut dikarenakan secara umum LKPD yang dianalisis memiliki skor yang kurang pada kategori objects/events, dimana peristiwa utama disertai objek dapat diidentifikasi dan konsisten dengan focus question hanya saja tidak mendukung dengan apa yang akan ditulis. Kegiatan LKPD hanya mengarahkan siswa untuk mengamati keadaan sel saat terjadi persitiwa plasmolisis tanpa memberikan kontruksi pengetahuan yang memperkuat konsep dan prinsip mengenai bioproses yang terjadi di dalam sel, sehingga selain kategori objects/events yang mendapatkan skor rendah juga terdapat ketidaksesuaian knowledge claim, dimana terjadi penulisan data atau peristiwa yang tidak konsisten. Misalnya, pada salah satu LKPD yang menggunakan berbagai jenis konsentrasi larutan garam, setelah di uji coba kadaan sel di berbagai kondisi lautan hipertonik tidak memperlihatkan kondisi yang konsisten, atau terkadang konsentrasi yang rendah lebih memperlihatkan

\section{Hudah, dkk}


peristiwa plasmolisis yang jelas dibanding konsentrasi larutan yang pekat. Hasil seperti ini akan membingungkan peserta didik. Proses rekontruksi LKPD dilakukan juga pada kegiatan praktikum untuk dapat memberikan knowedge claim yang sesuai dengan tujuan praktikum yang ingin dicapai, penggunaan konsentrasi yang memiliki perbedaan ekstrem seperti penggunaan larutan garam 0\% dan larutan garam 15\% dilakukan dan diberikan pada preparat sayatan epidermis Rheo discolour yang sama untuk dapat memperlihatkan gejala peristiwa plasmolisis pada sel tumbuhan sesuai dengan tujuan, dan diberikan pula pertanyaan yang menuntut hasil analisis siswa mengenai kegiatan praktikum yang dilakukan.

\section{KESIMPULAN}

Dari hasil analisis, uji coba dan rekontruksi enam LKPD memgenai pengamatan plasmolisis pada sel tumbuhan dapat memberikan gambaran bahwa sebagian LKPD masih belum layak untuk digunakan sebagai acuan kegiatan praktikum karena memperlihatkan ketidaksesuaian di beberapa indikator baik pada analisis konseptual, analisis praktikal dan analisis rekontruksi pengetahuan. Hal ini, dikarenakan pada dasarnya LKPD yang di buat belum sesuai dengan rujukan kurikulum yang berlaku sehingga perlu dikaji ulang antara tujuan dan kegiatan praktikum harus konsisten. Selain daripada itu, yang tak kalah penting adalah penyajian prosedur kerja yang terstruktur akan membantu siswa memahami dan melaksanakan kegiatan praktikum dengan baik. Analisis rekontruksi pengetahuan pun belum mengarahkan siswa untuk menghubungkan fakta yang di dapat dari praktikum untuk membentuk suatu konsep, hingga memahami prinsip dari proses yang terjadidi dalam sel. Analisis dari diagram vee semakin memperkuat kelemahan kualitas LKPD yang digunakan guru-guru untuk membelajaran peserta didiknya. Bahkan. beberapa LKPD yang digunakan pada periode kurikulum sebelumnya menunjukan kualitas yang lebih baik dibanding LKPD yang digunakan untuk periode saat ini. Hal ini menunjukkan kemunduran kualitas penyusunan LKPD, sehingga diperlukan rekontriksi lembar kerja yang sesuai dengan tuntutan kurikulum dan tujuan dari pembelajaran.

\section{DAFTAR PUSTAKA}

Afsari. (2017). Pengembangan Lembar Kerja Peserta DIDIK Berpikir Tingkat Tinggi Pada Pokok Bahasan Sel Kelas XI IPA SMA NEGERI 16 Makassar. Makassar: Universitas Islam Negeri Alauddin: Tidak diterbitkan.

Andi Prastowo. (2011). Panduan Kreatif Membuat Bahan Ajar Inovatif: Menciptakan Metode Pembelajaran yang Menarik dan Menyenangkan. Yogyakarta: Diva Press.

Emda, Amna. (2014). Laboratorium Sebagai Sarana Pembelajaran Kimia Dalam Meningkatkan Pengetahuan dan Keterampilan Kerja IImiah. Lantanida Journal, 2(2). 218-229. https://doi.org/10.22373/li.v2i2.1409 
Hasni, Abdelkrim. (2016). The Teaching and Learning of Diffusion and Osmosis: What Can We Learn from Analysis of Classroom Practices? A Case Study. Eurasia Journal of Mathematics, Science \& Technology, 12(6). 1507-1531. https://doi.org/10.12973/eurasia.2016.1242a

Hartono, Z., dan Ibrahim, R. (2014). Pengembangan Buku Panduan Praktikum Kimia Hidrokarbon Berbasis Keterampilan Proses Sains di SMA. Jurnal Pendidikan Kimia, 1(4). 87-93. https://doi.org/10.36706/jppk.v1i1.2228

Huzaifah, Siti, et.al. (2017). Penerapan Diagram Vee untuk Meningkatkan Hasil Belajar Mahasiswa Program Studi Pendidikan Biologi Pada Mata Kuliah Metodologi Penelitian. Prosiding Semianr Nasional Pendidikan IPA 2017. 610620. http://conference.unsri.ac.id/index.php/semnasipa/article/view/724

Katriani, Laila. (2014). Pengembangan Lembar Kerja Peserta Didik (LKPD). Pelatihan Pembuatan Perencanaan Pembealajaran IPA. Universitas Negeri Yogyakarta: Tidak diterbitkan

Lang, Ingeborg, et.al. (2014). Plasmolysis: Loss of Turgor and Beyond. Plants, 3. 583-593. https://doi.org/10.3390/plants3040583

Millar, R. (2004). The Role of Practical Work in The Teaching and Learning of Science. Washington DC. National Academy of Sciences

Mentari, setiawati., et. al. (2017). Efektifitas Praktikum Berbasis Guided Inquiry Diintegrasikan dengan Video Transfer Membran Terhadap Keterampilan Proses Sains (KPS) dan Pemahaman Konsep Siswa. Journal of Buology Education, 6(1). 45-55. https://doi.org/10.15294/ibe.v6i1.14055

Novak. J.D.\& Gowin D.B. (1984). Learning how to learn.USA: Cambridge University Press.

Oztas, Fulya. (2013). How do High Scgool Students Know Diffusion and Osmosis? High School Students' Difficulties in Understanding Diffusion \& Osmosis. Procedia - Social and Behavioral Sciences, 116. 3678-3682. https://doi.org/10.1016/j.sbspro.2014.01.822

Rahmatilla, el.al. (2017). Pengembangan Lembar Kerja Peserta Didik Berbasis Keterampilan Proses Sains Terhadap AKtivitas Pada Materi Koloid. Jurnal IPA dan Pembelajaran IPA, 1(2). 121-130. https://doi.org/10.24815/iipi.v1i2.9686

Sari, Yeni Pita, et.al. (2018). Pengembangan Lembar Kerja Peserta Didik Bedasarkan Studi Pengaruh Osmosis Terhadap Warna Mata. Jurnal Pendidikan dan Pembelajaran Biologi, 2(2). 16-21. https://doi.org/10.33369/diklabio.2.2.16-21

Sudarsiman, Suciati. (2015). Memahami Hakikat dan Karakteristik Pembelajaran Biologi dalam Upaya Menjawab Tantangan Abad 21 Serta Optimalisasi Implementasi Kurikulum 2013. Jurnal Florea, 2(1). 29-35. http://doi.org/10.25273/florea.v2i1.403

Sugiyono. 2016. Statistika Untuk Penelitian. Bandung: Penerbit Alfabeta Bandung. 
Supriatno, B. (2009). Uji Langkah Kerja Laboratorium Sekolah. Proseding Seminar Nasional Biologi: Inovasi dan Pendidikan Biologi dalam Pengembangan Sumber Daya Manusia. 255-261.

Supriatno, B. (2013). Pengembangan Program Perkuliahan Pengembangan Praktikum Biologi Sekolah Berbasis ANCORB untuk Mengembangkan Kemampuan Merancang dan Mengembangkan Desain Kegiatan Laboratorium. Disertasi Jurusan Pendidikan Biologi FPMIPA UPI: Tidak diterbitkan

Sujarweni. V. Wiratna. 2012. Statistika untuk Penelitian. Yogyakarta: Graha llmu.

Wahidah, Nur Sopiah, et.al. (2018). Analisis Struktur dan Kemunculan Tingkat Kognitif pada Desain Kegiatan Laboratorium Materi Fotosintesis. Indonesia $\begin{array}{llll}\text { Journal of Biology Education, 1(2). } & \text { 70-76. }\end{array}$ https://doi.org/10.17509/aijbe.v1i2.13050

Widjajanti, E. (2008). Kualitas Lembar Kerja Siswa. Jurnal Pendidikan FMIPA: Universitas Negeri Yogyakarta.

Umbaryati. (2016). Pentingnya LKPD Pada Pendeketan Scientific Pembelajaran Matematika. Tesis FMIPA Universitas Lampung: Tidak diterbitkan. 